\author{
I.M. Kurmakova ${ }^{1}$, O.S. Bondar ${ }^{1}$, I.V. Holub ${ }^{1}$, A.A. Korolev ${ }^{2}$
}

\title{
Dynamics of Protective Layers Formation during Steel Inhibition by Sulfanilamide in Hydrochloric Acid Solutions with Different pH
}

\author{
${ }^{I}$ T.H. Shevchenko National University "Chernihiv Colehium", Chernihiv, Ukraine, i.kurmakova@gmail.com \\ ${ }^{2}$ State Scientific Research Institute of Armament and Military Equipment Testing and Certification, Chernihiv, Ukraine \\ Using the method of polarization resistance, it has been proved that there are peculiarities in the formation of \\ protective layers during steel inhibition by Sulfanilamide in aqueous solutions of hydrochloric acid with different \\ $\mathrm{pH}$, resulting from the predominance of protonated or deprotonated forms of molecules. At $\mathrm{pH} \leq 2.4$ \\ (predominantly protonated form) dense protective films are formed, while at $\mathrm{pH} \geq 2.4$ (predominantly \\ deprotonated form) loose layers are formed that do not inhibit diffusion processes. High $(>90 \%)$ and stable \\ efficiency of Sulfanilamide inhibition in acidic media can be provided only by the protective films formed of \\ protonated molecules, which must be considered when using the inhibitor.
}

Key words: acid corrosion, inhibition, structural steel, Sulfanilamide, polarization resistance.

Received 28 May 2021; Accepted 02 July 2021.

\section{Introduction}

The interaction of organic substances with the metal surface causes a wide range of their action, including corrosion inhibition due to adsorption and the formation of protective layers. As the mechanism and kinetics of protective layers formation determine the effectiveness of corrosion protection, this issue is important for the study of corrosion inhibitors. It was defined that physical adsorption is typical for imidazo[1,2-a]pyridinium bromides [1], and chemisorption, which is more efficient at slowing down corrosion processes, is typical for imidazo[1.2-a]azepine bromides [2], polymethyleneimidazoline bromides [3], secondary amines with triazoloazepine and substituted phenyl radicals [4-7].

Scientists [8-10] demonstrated that compounds containing amino groups, in particular guanidine, amino acids, etc., can act as ligands in forming the phase layers of slightly soluble inhibitor compounds with corroding metal cations, which reduces the rate of steel corrosion in acid solutions. However, the peculiarity of organic amines and other compounds with a functional amino group is a change in the degree of protonation and, accordingly, the form of existence in media with different $\mathrm{pH}$. This change can significantly affect the redistribution of charges, the ability to adsorb or form complexes, the patterns of protective layers formation. Nevertheless, it has not been an object of a thorough research yet [11].

R.Yildz and al. [12] determined high anticorrosive properties of Sulfanilamide in acid media $(0.5 \mathrm{M} \mathrm{HCl})$ and its ability to form protective films. For more effective and predictable corrosion protection with this inhibitor, it is important to study the dynamics of the protective layers formation depending on the medium $\mathrm{pH}$ and, accordingly, the degree of molecules protonation.

\section{Research aim}

The aim of this paper is to study the dynamics of protective layers formation during the inhibition of structural steel corrosion by Sulfanilamide in acid chloride media with different $\mathrm{pH}$, which causes different degrees of molecule protonation. 


\section{Experimental}

The form of existence and the share of protonated Sulfanilamide (SA) molecules in acidic solutions $(\mathrm{pH}<7)$ were defined using ACD/Log D (ACDLabs 6.0., Advanced Chemistry Development Inc.) software package. Based on the obtained data, hydrochloric acid solutions with a $\mathrm{pH}$ value, in which the molecules are mainly protonated $(\mathrm{pH}=0$ and 1) and mainly deprotonated $(\mathrm{pH}=2.4$ and 4$)$, were selected for the study.

Molecule atoms charges and energy characteristics (energy of the highest occupied molecular orbital $\mathrm{E}_{\mathrm{HOMO}}$ and energy of the lowest unoccupied molecular orbital - $\left.\mathrm{E}_{\text {LUMO }}\right)$ were calculated using the software program Chem3D 9.0 (Cambrige Soft).

The dynamics of protective layers formation was studied by the magnitude of polarization resistance, which is inversely proportional to the corrosion rate and is a parameter that characterizes the thickness of the film formed on the surface [13]. Indicator P5126, which is a two-electrode electrochemical transducer consisting of two identical cylindrical electrodes made of steel 20 (diameter - $6 \mathrm{~mm}$, length - $30 \mathrm{~mm}$, area of each electrode $-6 \mathrm{~cm}^{2}$, distance between electrodes $-7 \mathrm{~mm}$ ) was used to determine the polarization resistance. Before the measurements, the steel samples were machinepolished until a surface roughness of no more than 0.8 , degreased in alcohol and stored in a desiccator. Polarization resistance $\left(R_{p}\right)$, which reflects the resistance to anodic and cathode processes $\left(R_{\mathrm{pa}}=\Delta \varphi_{\mathrm{a}} / \mathrm{i} ; \mathrm{R}_{\mathrm{pK}}=\Delta \varphi_{\mathrm{K}} / \mathrm{i}\right.$, where $\Delta \varphi_{\mathrm{a}}, \Delta \varphi_{\mathrm{K}}$ - anodic and cathodic polarization, B; i corrosion current density, $\mathrm{A} / \mathrm{m}^{2}$ ), was measured periodically for 4 hours after reaching steady state.

Sulfanilamide corrosion efficiency was studied by massometry method using samples of structural steel $\mathrm{St} 3 \mathrm{ps}$ in acid chloride media. Before the study, the steel samples (surface area $0.0027 \mathrm{~m}^{2}$ ) were polished to $4-5$ accuracy class, degreased with ethyl alcohol and weighed on analytical scales with an accuracy of $5 \cdot 10^{-5} \mathrm{~g}$. Sample's exposure time was 6 hours. Test temperature $293 \pm 2 \mathrm{~K}$ and $313 \pm 2 \mathrm{~K}$, inhibitor concentration 10 $\mathrm{mmol} / \mathrm{l}$. After studies on the surface of the samples of visible corrosion products were not observed. The samples were soaked in distilled water, dried, and weighed again with analytical scales. The obtained results were used to calculate the corrosion rate without and with an inhibitor $\left(\mathrm{k}_{\mathrm{m}}=\Delta \mathrm{m} /(\mathrm{S} \cdot \tau)\right.$, where $\Delta \mathrm{m}$ is the samples weight loss, $\mathrm{g} ; \mathrm{S}$ is the sample area, $\mathrm{m}^{2} ; \tau$ is time, h), the corrosion inhibition coefficient $\left(\gamma=\mathrm{k}_{\mathrm{m}} / \mathrm{k}_{\mathrm{m}}{ }^{\prime}\right.$, where $\mathrm{k}_{\mathrm{m}}, \mathrm{k}_{\mathrm{m}}$ '- corrosion rate without and without the inhibitor), inhibition efficiency (IE $=(1-1 / \gamma) \cdot 100 \%)$.

The accuracy of experimental determination of the corrosion rate by the massometry method and the method of polarization resistance with the number of measurements $n=5$, is $\pm 5 \%$ with a probability of 0.95 .

The redox potential $(\mathrm{E}, \mathrm{mV})$ of the corrosive medium was measured using a sensor and a recorder LabQuest 2 (Vernier Software \& Technology). Comparison electrode was chlorine silver. Measurement error $\pm 0.5 \mathrm{mV}$.

\section{Results and discussion}

The polarization resistance, which is directly related to the moment corrosion rate (inversely proportional), is much higher in Sulfanilamide-inhibited hydrochloric acid solutions than in non-inhibited (Fig. 1, a-d).

This is consistent with SA molecule structure (the presence of two amino groups, Sulfur and Oxygen atoms, which can act as adsorption-reaction centers when interacting with metal surface), its energy characteristics $\left(\mathrm{E}_{\mathrm{LUMO}}=-1.087 \mathrm{eV} ; \mathrm{E}_{\text {Hомо }}=-10.459 \mathrm{eV}\right.$, indicating electrophilic properties of the molecule and high reactivity), the data obtained by massometry method (Table) and the results of SA study presented in [12].

The authors [10] demonstrated that the total polarization resistance can be used as a criterion for controlling the thickness of the protective film that forms on the steel sample surface. It should be noted that the nature of the change in $\mathrm{Rp}$ over time differs significantly for the studied inhibited chloride media (Fig. 1). This indicates the peculiarities of the interaction of protonated ( $\mathrm{pH} 0$ and 1) and deprotonated ( $\mathrm{pH} 2.4$ and 4) SA molecules (Table) with the steel electrode surface in solutions with a certain $\mathrm{pH}$ and the protective layers formation.

The increase in polarization resistance at $\mathrm{pH}=0$ (Fig. 1-a) and $\mathrm{pH}=1$ (Fig. 1-b) in the solutions where SA molecules are predominantly protonated occurs by a close to exponential law. Its greatest increase is observed during the first 30-60 minutes, then the value of the polarization resistance almost stabilizes. Processing of experimental data in the coordinates $R_{p}-f\left(\tau_{1 / 2}\right)$ provides linear dependences (Fig. 2) with high approximation coefficients $\left(\mathrm{R}^{2}\right) 0.89$ and 0.94 for $\mathrm{pH}=0$ and $\mathrm{pH}=1$ respectively.

This allows us to conclude that dense protective films are formed when their growth rate is limited by the diffusion rate of reagents or reaction products. As shown in [13], the condition for their formation can be considered the implementation of the following equation:

$$
\mathrm{Rp}=(2 \cdot \mathrm{D} \cdot \mathrm{C})^{0.5} \cdot \rho \cdot \mathrm{t}^{0.5},
$$

where $\mathrm{D}$ and $\mathrm{C}$ are the diffusion coefficient and the concentration of particles involved in the film growth process.

The obtained results are also consistent with the results of SEM, which are presented in [12]. The formed film is quite strong, resulting in high protective properties of SA (Table), which do not decrease with temperature increase: in $0.1 \mathrm{M} \mathrm{HCl}$ at SA concentration of $10 \mathrm{mmol} / \mathrm{l}$, the inhibition efficiency at $313 \mathrm{~K}$ is $99.1 \%$.

The control of the corrosive medium redox potential $(1 \mathrm{M} \mathrm{HCl})$ reveals that without $\mathrm{SA}$ there is a slow decrease in $\mathrm{E}$ (Fig. 3), which is consistent with an increase in polarization resistance (Fig. 1-a). In the presence of Sulfanilamide in the media the redox potential increases in the first 20 minutes, which may indicate the formation of slightly soluble complex compounds of the inhibitor with corroding metal cations similar to guanidine and a number of amino acids [8-10].

In solutions with $\mathrm{pH}=2.4$ and 4 , the polarization resistance significantly increases first (Fig. 1-c, d), and then constantly decreases. This indicates that 
I.M. Kurmakova, O.S. Bondar, I.V. Holub, A.A. Korolev

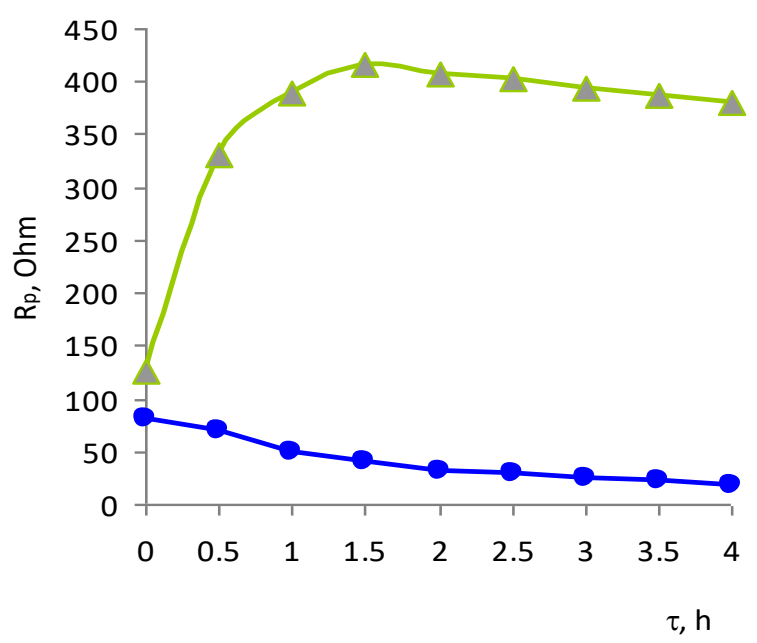

a

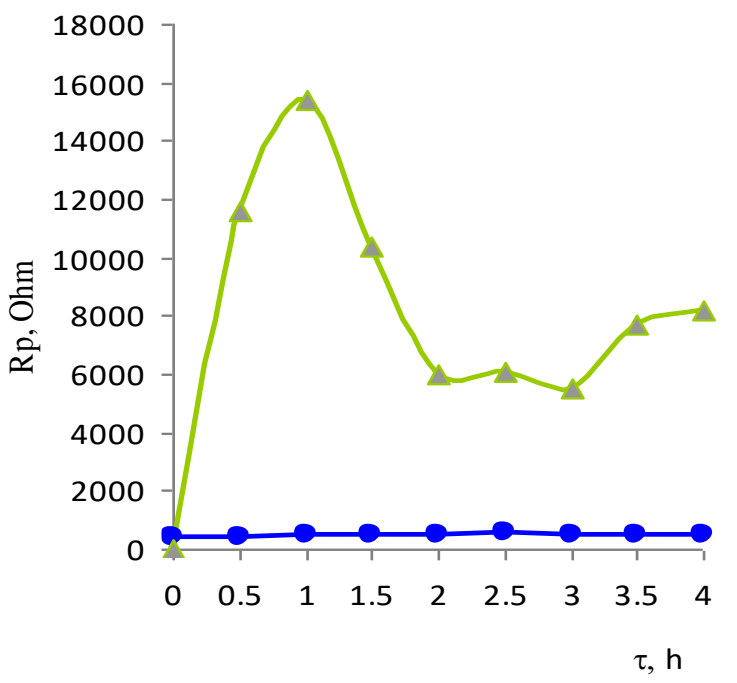

c

$\mathrm{HCl}$

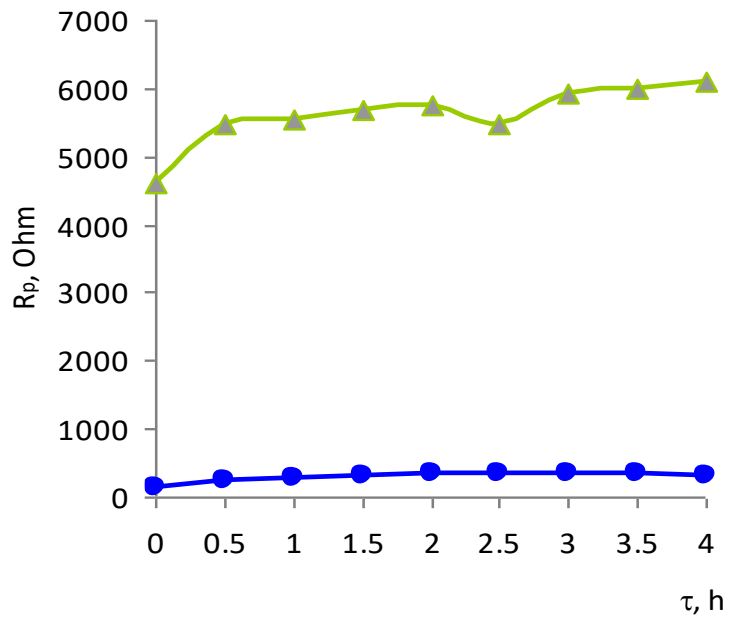

b

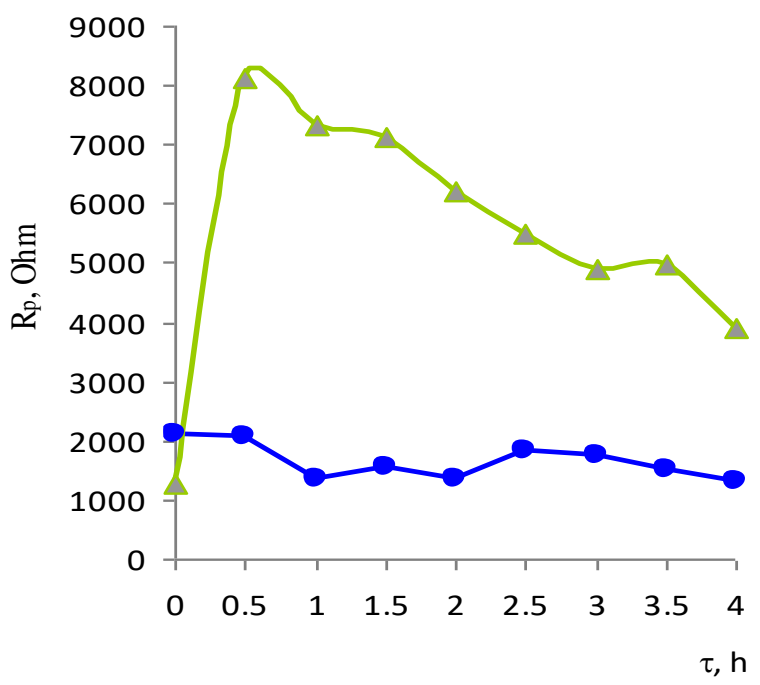

d

Fig. 1. Correlation between polarization resistance and time in non-inhibited and SA inhibited solutions of hydrochloric acid: a) $\mathrm{pH}=0$; b) $\mathrm{pH}=1$; c) $\mathrm{pH}=2.4$; d) $\mathrm{pH}=4$.

Table

SA molecules existence forms in hydrochloric acid solutions with different $\mathrm{pH}$ and inhibition efficiency at $293 \mathrm{~K}$

\begin{tabular}{|c|c|c|c|c|}
\hline \multirow{2}{*}{$\mathrm{pH}$} & \multicolumn{2}{|c|}{ Share of the corresponding form of sulfonamide molecules in solution } & \\
\hline 0 & 0.017 & 0.983 & 15.2 & 93.4 \\
\hline 1 & 0.144 & 0.856 & 18.5 & 94.6 \\
\hline 2.4 & 0.809 & 0.191 & 11.0 & 90.9 \\
\hline 4 & 0.994 & 0.006 & 14.2 & 92.9 \\
\hline
\end{tabular}

deprotonated SA molecules due to the appropriate distribution of electrostatic potential, form loose surface layers that do not provide sufficient density for the penetration of corrosive media to the steel surface.
The deprotonated form (Fig. 4-a) is characterized by a very low positive charge $(+0.008)$ on the Nitrogen atom of the amino group bound with the benzene ring, a negative charge $(-0.457)$ on the Nitrogen atom of the amino group bound with the positively charged $(+2.213)$ Sulfur atom. Thus, in deprotonated molecules, the amino 


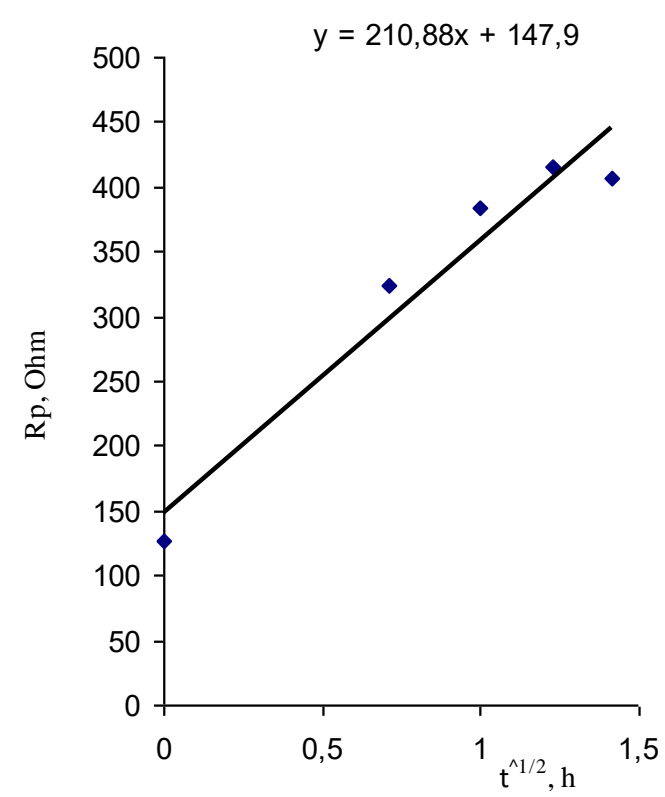

a

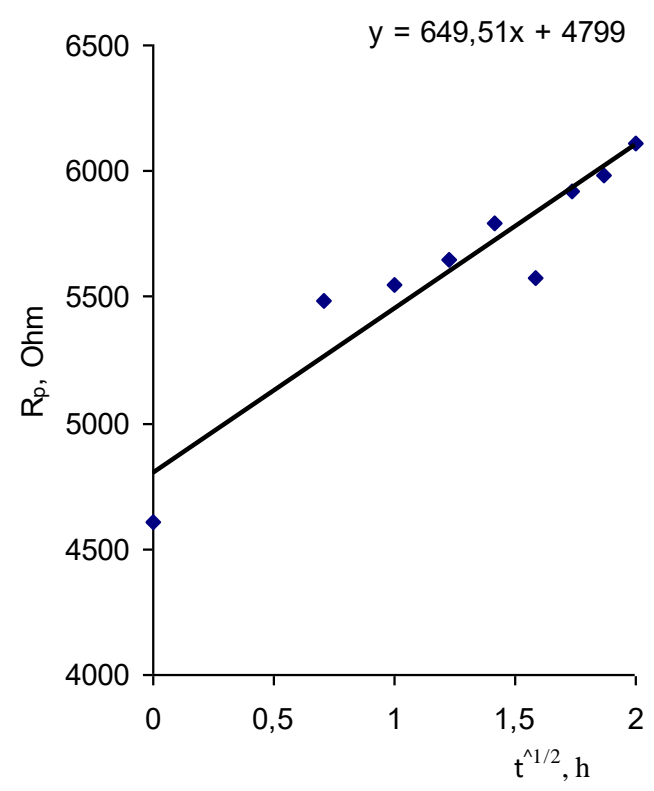

b

Fig. 2. Correlation between polarization resistance and soaking time in inhibited SA solutions of hydrochloric acid in the coordinates: $\mathrm{R}-\mathrm{f}\left(\mathrm{h}^{1 / 2}\right)$ : a) $\mathrm{pH} 0$; b) $\mathrm{pH} 1$.

group that binds with the benzene nucleus doesn't serve as a possible adsorption-reaction center in contrast to protonated molecules (Fig. 4-b), in which this Nitrogen acquires a charge $(+0.484)$.

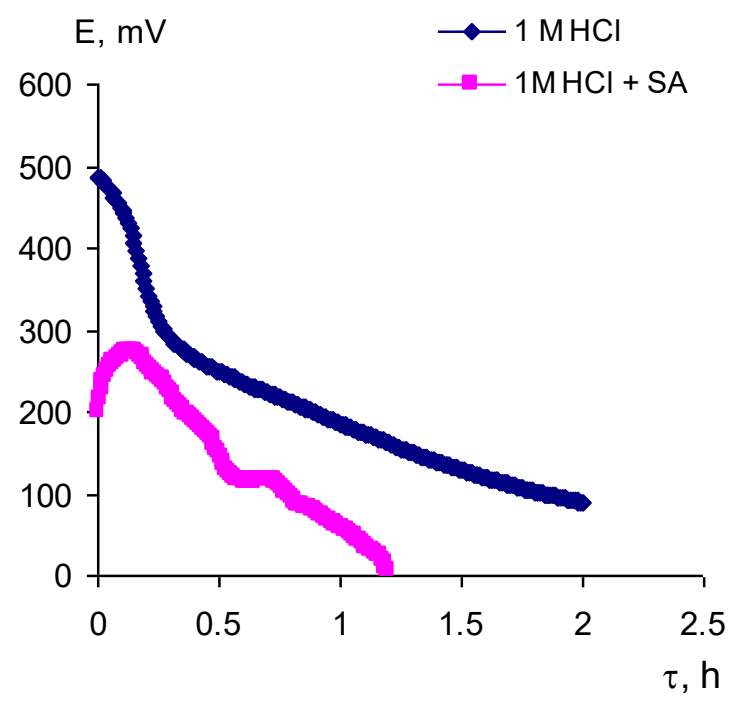

Fig. 3. Correlation between the redox potential of corrosive medium $(1 \mathrm{M} \mathrm{HCl})$ and time.

It is worth noting that SA inhibition efficiency in solutions with $\mathrm{pH}=2.4$ and 4 (table) defined at $6 \mathrm{~h}$ of samples testing does not differ significantly from the results for solutions with $\mathrm{pH}=0$ and 1 . It should be expected that the formation of protective layers with different densities will occur during long-term testing of the SA anti-corrosion properties or provide unstable protection when used in acidic media with a $\mathrm{pH}$ of $\geq 2.4$.

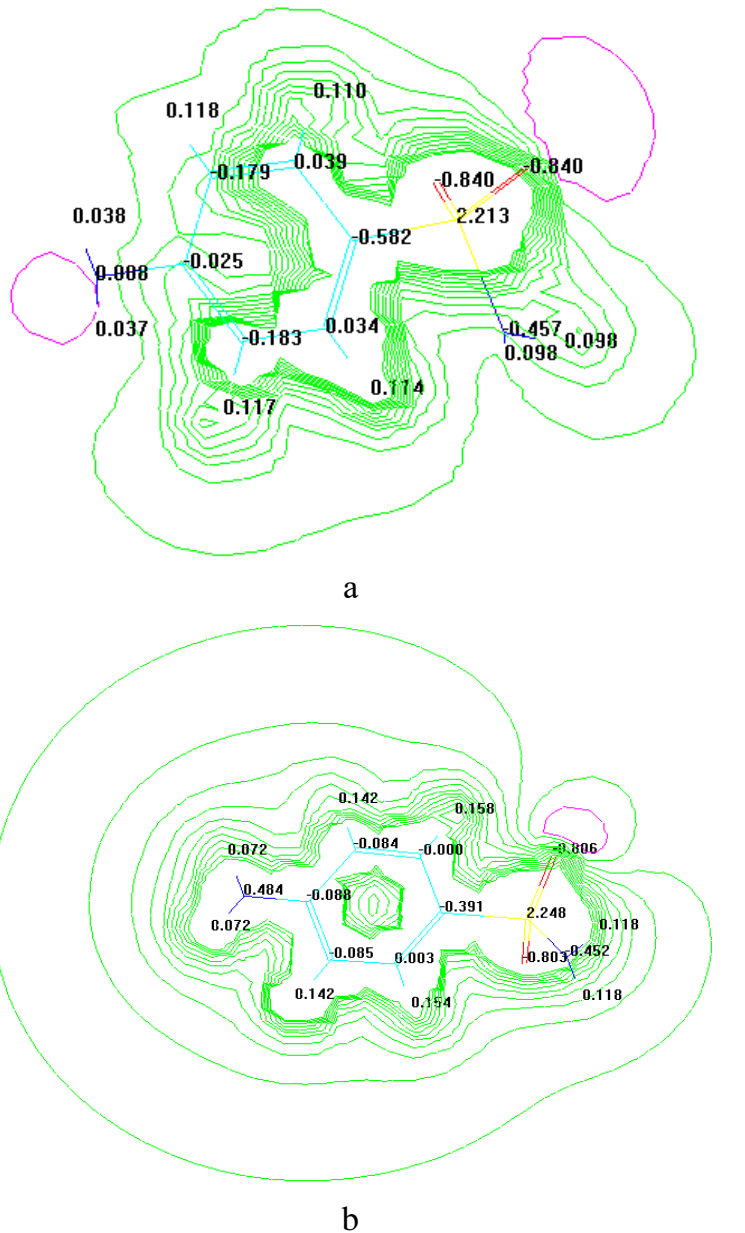

Fig. 4. Distribution of charges and electrostatic potential in the Sulfanilamide molecule: $\mathrm{a}$ - deprotonated form; $\mathrm{b}$ protonated form. 


\section{Conclusion}

The formation of protective layers during steel inhibition by Sulfanilamide in aqueous solutions of hydrochloric acid with different $\mathrm{pH}$ depends on the form of molecules existence. The method of polarization resistance shows that in the presence of predominantly protonated molecules $(\mathrm{pH} \leq 2.4)$ in the solution dense protective films are formed. When the deprotonated molecules predominate $(\mathrm{pH} \geq 2.4)$, loose layers are formed that do not inhibit diffusion processes. Stable and highly efficient inhibition by Sulfanilamide (>90\%) is ensured only by protective films formed from protonated molecules, which must be taken into account when using the inhibitor.

Kurmakova I.M. - professor, Sc.D in Technical Science, head of department of chemistry, technology and pharmacy;

Bondar O.S. - associate professor, Ph.D in Technical Science, associate professor of department of physics and astronomy;

Holub I.V. - master of Faculty of Natural Sciences and Mathematics;

Korolev A.A. - associate professor, Ph.D in Technical Science, leading researcher.

[1] V.G. Starchak, I.N. Kurmakova, Zh.V. Zamai, E.M. Novikova, A.M Demchenko, N.A. Kuzyna, Russian journal of applied chemistry 69(7), 987 (1996).

[2] V.N. Chelyabieva, N.V. Smykun, I.N. Kurmakova, Protection of Metals 39(4), 353 (2003).

[3] I.N. Kurmakova, S.V. Prikhod'ko, N.V. Smykun, A.P. Tretyak, Protection of Metals 39(4), 357 (2003).

[4] A.M. Demchenko, K.G. Nazarenko, A.P. Makei, S.V. Prikhod'ko, I.N. Kurmakova, A.P. Tretyak, Russian journal of applied chemistry 77(5), 790 (2004); https://doi.org/10.1023/B:RJAC.0000038814.13877.49.

[5] I.N. Kurmakova, S.V. Prykhodko, Bulletin of the National Technical University «KhPI»32, 88 (2008).

[6] O.S. Bondar, S.V. Prykhod'ko, I.M. Kurmakova, O.L. Humenyk, Materials Science 47(3), 370 (2011).

[7] I.M. Kurmakova, O.S. Bondar, V.I. Vorobyova, M.I. Skiba, S.V. Tkachenko, O.P. Makey, International Journal of Corrossion and Scale Inhibition, 7 (4), 582 (2018); https://doi.org/10.17675/2305-6894-2018-7-4-7.

[8] Yu.P. Vyshnevska, T.Yu. Nyzhnyk, D.A. Tkalenko, I.M. Astrelin, Reports of the National Academy of Sciences of Ukraine 8, 121 (2008).

[9] D.A. Tkalenko, G.Venkatesvaran, Yu.P. Vishevskaya, et al., Protection of Metals and Physical Chemistry of Surfaces, 46(5), 609 (2010).

[10] Yu.S. Tsyrulova, D.A. Tkalenko, Yu.P. Vyshnevska, Yu.V. Savchenko, Issues of Chemistry and Chemical Technology 4(2), 263 (2011).

[11] O.O. Korolev, O.S. Bondar, I.M. Kurmakova, O.I. Syza, Issues of Chemistry and Chemical Technology 3, 101 (2020); https://doi.org/10.32434/0321-4095-2020-130-3-101-107.

[12] R. Yildiz, S. Toprak Döşlü, İ. Dehri, XV International Corrosion Symposium (Antakya, 2018); http://acikerisim.artuklu.edu.tr/xmlui/handle/20.500.12514/974.

[13] D.A. Tkalenko, Yu.P. Vyshnevs'ka, Yu.S. Herasymenko, I.F. Khirkh-Yalan, Materials Science, 49,304 (2013); https://doi.org/10.1007/s11003-013-9615-1.

\title{
I.М.Курмакова ${ }^{1}$, О.С.Бондар ${ }^{1}$, І.В.Голуб ${ }^{1}$, О.О.Корольов ${ }^{2}$
}

\section{Динаміка формування захисних шарів при інгібуванні сталі сульфаніламідом у розчинах хлоридної кислоти з різним рН}

\author{
${ }^{1}$ Національній університет «Чернігівський колегіум» імені Т.Г. Шевченка, м. Чернігів, Украӥна, \\ i.kurmakova@gmail.com \\ ${ }^{2}$ Державний науково-дослідний інститут випробувань і сертифікаиії озброєння та військової техніки, \\ м. Чернігів, Украӥна
}

\begin{abstract}
Методом поляризаційного опору доведено, що формуванння захисних шарів при інгібуванні сталі сульфаніламідом у водних розчинах хлоридної кислоти з різним $\mathrm{pH}$ має особливості зумовлені переважанням протонованої або непротонованої форм молекул. При $\mathrm{pH} \leq 2,4$ (переважає протонована форма) формуються щільні захисні плівки, при $\mathrm{pH} \geq 2,4$ (переважає непротонована форма) утворюються пухки шари, які не гальмують дифузійні процеси. Високу (> 90 \%) та стабільну ефективність інгібування сульфаніламіду в кислих середовищах здатні забезпечувати лише захисні плівки сформовані 3 протонованих молекул, що необхідно враховувати при його застосуванні. опір.

Ключові слова: кислотна корозія, інгібування, конструкційна сталь, сульфаніламід, поляризаційний
\end{abstract}

